\title{
Neuroendocrine breast cancer
}

\author{
Susana Graça, Joana Esteves, Sílvia Costa, Sílvio Vale, Jorge Maciel
}

General Surgery Department, Centro Hospitalar Gaia/Espinho, Gaia, Portugal

Correspondence to Dr Susana Alexandra Rodrigues Graça, sarga3@gmail.com

\begin{abstract}
Summary
Neuroendocrine breast cancer is thought to account for about $1 \%$ of all breast cancers. This rare type of breast malignancy is more common in older women and presents as a low-grade, slow-growing cancer. The most definitive markers that indicate neuroendocrine carcinoma are the presence of chromogranin, synaptophysin or neuron-specific enolase, in at least $50 \%$ of malignant tumour cells. The authors present a case report of an 83-year-old woman, admitted to their institution with right breast lump. Physical examination, mammography and ultrasonography showed a $2.4 \mathrm{~cm}$ nodule, probably a benign lesion (BI-RADS 3). A fine needle aspiration biopsy was performed and revealed proliferative epithelial papillary lesion. She was submitted to excisional biopsy and histology showed endocrine breast cancer well differentiated (G1). Immunohistochemically, tumour cells were positive for synaptophysin. These breast cancers are characterised for their excellent prognosis and conservative treatment is almost always enough to obtain patient cure.
\end{abstract}

\section{BACKGROUND}

Neuroendocrine breast cancer (NBC) is thought to account for about $1 \%$ of all breast cancers. ${ }^{1}$ Its etiology is not certain, but it is possible to originate from the mammary gland or from neuroectodermic cells which migrate to the ductal system. ${ }^{2}$

This type of breast malignancy is more common in older women, increasing in frequency with age. However, $5.8 \%$ of these neoplasms are reported in men. ${ }^{3}$

Usually this type of carcinoma present as a low-grade, slow-growing disease. Histologically, NBC is constituted by groups of cells, separated by vascularised stroma and colageneous bands, producing a papillary and microglandular pattern. ${ }^{4}$

The most definitive markers that indicate neuroendocrine carcinoma are the presence of chromogranin, synaptophysin or neuron-specific-enolase, occurring in at least $50 \%$ of malignant cells.

The WHO classifies these tumours in three main histologic patterns: solid (well differentiated with the best prognosis), small cell and large cell variant. ${ }^{5}$

NBC is morphologically similar to those in gastrointestinal tract and lung, but it is not common to present as a carcinoid syndrome. ${ }^{4}$

As this is a rare disease, unknown by many health professionals, the authors choose to present this misleading case report that seemed to be a benign lesion, but in fact hid a neuroendocrine tumour.

\section{CASE PRESENTATION}

An 83-year-old Caucasian woman, with history of diabetes and arterial hypertension, was send to general surgery consultation for right breast lump.

The patient presented without any complaint associated with the lump. Physical examination revealed a palpable right breast $2 \mathrm{~cm}$ nodule in the superior and internal quadrants, painless, not adherent to deep layers, had an elastic consistency and smooth surface. The other breast and both underarms did not reveal alterations. The mammography suggested a benign nodule, with defined limits, no calcifications, that should be biopsied - BI-RADS 3 (figure 1). Ultrasonography confirmed $2.4 \mathrm{~cm}$ nodule with slightly heterogeneous content and not regular contours (benign appearance) (figure 2).

The patient was submitted to a fine needle aspiration biopsy (FNAB) which result was: proliferative epithelial papillary lesion; and proposed surgical conservative treatment that she accepted.

She underwent wide local nodule excision, with surgical closest margin of $1 \mathrm{~cm}$ and the histopathologic result showed: endocrine breast cancer, well differeniated (G1), solid pattern with round and irregular nuclei, organised in nests, with oestrogen and progesterone positive receptors. The imunohistochemistry revealed positivity to synaptophysin in more than $50 \%$ of tumour cells (figures 3 and 4). The expression of cytokeratin 7 was not tested.

After obtaining this histologic result, the patient was asked for symptoms suggestive of a neuroendocrine non-
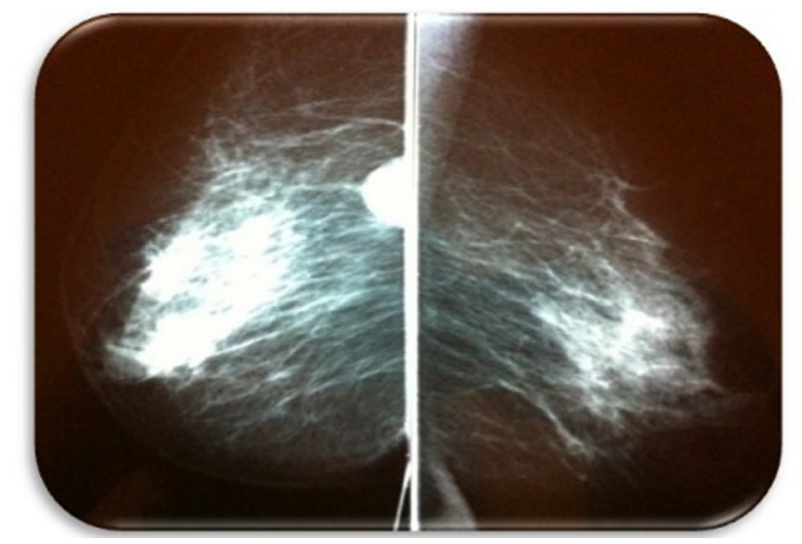

Figure 1 Mammography image of a $2 \mathrm{~cm}$ right breast lump probably benign (BI-RADS 3 ), with defined limits and no calcifications. 


\section{BMJ Case Reports}

mammary tumour, such as flushing, diarrhoea, abdominal cramping, wheezing, peripheral oedema, heart palpitations and others, which she denied. Then she was submitted to a thoraco-abdominal tomography, upper and lower endoscopy and octreoscan, all negative, excluding metastatic neuroendocrine tumour.

\section{OUTCOME AND FOLLOW-UP}

- Multi-disciplinary oncological group decided for hormone therapy, sentinel node biopsy (which was negative) and octreoscan (also negative).

- Follow-up without evidence of disease.

\section{DISCUSSION}

The authors request attention to this case report because of the rarity of the NBC, unknown by plenty of health professionals and the misleading character of the lump.

Neuroendocrine tumours can metastasise to the breast, representing approximately 1 to $2 \%$ of all breast tumours. ${ }^{6}$ In a review of the literature, Upalakalin reported 59 cases of carcinoid breast tumours, 38 primary NBC, 21 metastatic ones, and from these, 9 were from an occult primary carcinoid. ${ }^{1} \mathrm{He}$ found out that these metastases presented on average 10 years earlier than primary NBC (6th and 7th decade of life). ${ }^{3}$

It is important to differentiate between a primary $\mathrm{NBC}$ and a metastatic one because of the differences in treatment. ${ }^{1}$

The diagnosis of a primary NBC may be made if nonmammary sites are excluded, as it was in our patient, or if there is the presence of a ductal carcinoma in situ component within the specimen, ${ }^{1}$ which did not happen in this case.

In this particular case, the absence of suggestive symptoms, the positivity to oestrogen and progesterone receptors and the negative octreoscan, support the diagnosis of primary NBC (metastatic neuroendocrine tumours to the breast typically have negative hormone receptors). ${ }^{7}$

As in this case, not always the FNAB or core biopsy can achieve the correct diagnose. Sometimes the papillary pattern formed by tumour cells, is mistaken by papillary lesions, so the final and correct diagnose of NBC is obtained only after surgery (histopathologic result).

There is a lack of clear recommendations regarding the surgical management of these uncommon tumours. Primary NBC should be treated as invasive ductal carcinoma is, including mastectomy or breast conservative surgery, as well as axillary staging with sentinel lymph node biopsy. ${ }^{1}$

The benefits of adjuvancy (hormone therapy, radiotherapy and chemotherapy) are not proved in the literature. ${ }^{3}$ Besides, our multi-disciplinary oncological group decided for the hormone therapy.

The clinical effect of NBC is still a matter of debate, however, when compared with unselected breast cancers, NBC shows a less aggressive clinical behaviour. ${ }^{8}$ Rovera et al studied 35 consecutive breast carcinomas with morphologic features suggestive of endocrine differentiation which undergone surgical treatment. They obtained $13 \mathrm{NBC}$ cases which were globally diagnosed later than other primary breast cancers, revealed no recurrent disease in 60 months follow-up unlike ductal and lobular carcinomas, concluding for the less aggressiveness of NBC. ${ }^{8}$

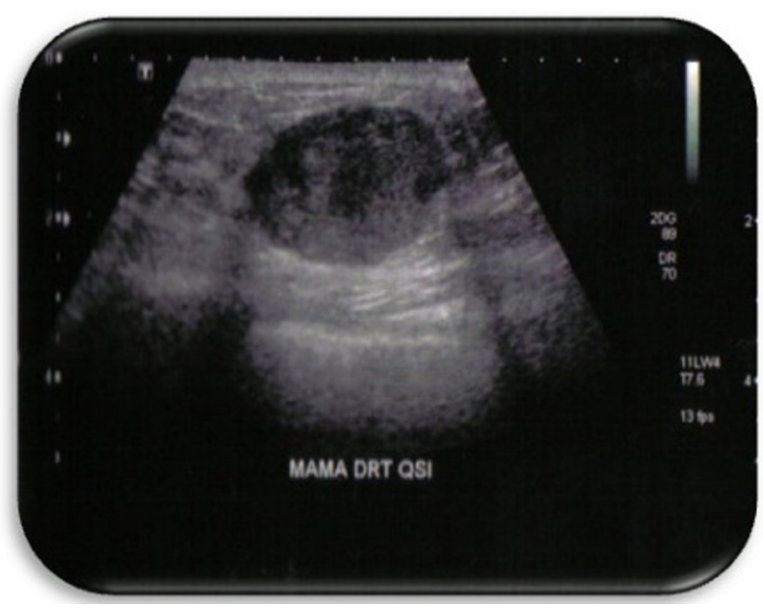

Figure 2 Ultrasonography image showing a $2.4 \mathrm{~cm}$ hipoechoic nodule with slightly heterogeneous content and regular contours.

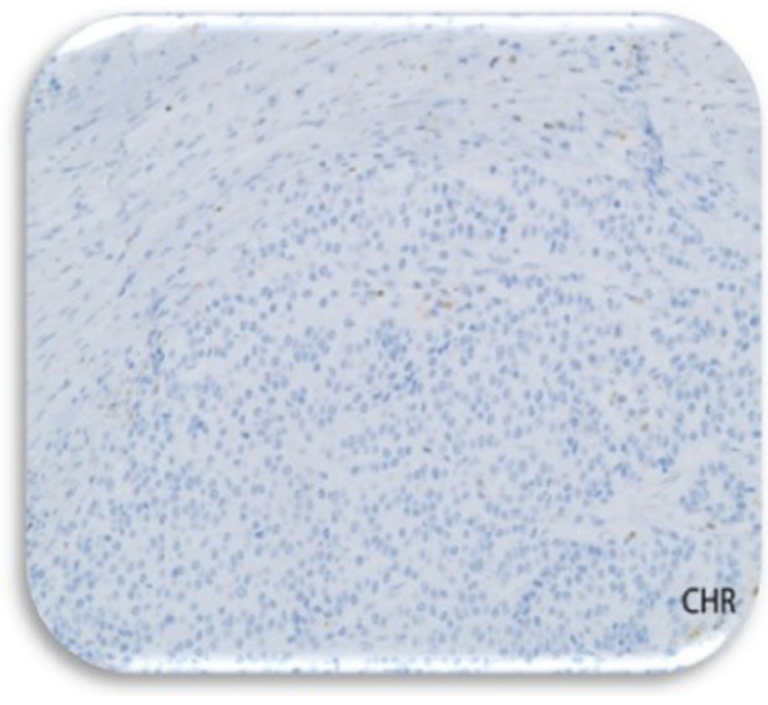

Figure 3 Immunohistochemistry - tumour cells negativity for chromogranin.

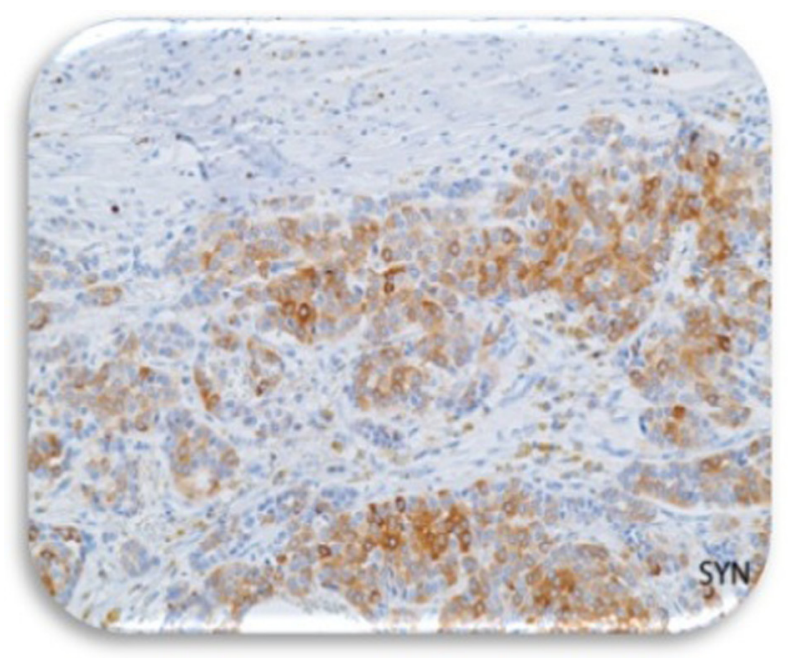

Figure 4 Immunohistochemistry - tumour cells positivity for synaptophysin. 


\section{BMJ Case Reports}

\section{Learning points}

NBC is a rare disease.

- This type of carcinoma is unknown by many health professionals.

- This is a misleading case because initially was thought to be a benign disease.

- NBC with solid pattern has good prognosis, better than other breast carcinomas.

- It behaves differently when compared with other breast neoplasms.

Competing interests None.

Patient consent Obtained.

\section{REFERENCES}

1. Upalakalin JN, Collins LC, Tawa N, et al. Carcinoid tumors in the breast. Am J Surg 2006;191:799-805.

2. Marta GN, Bergamasco VD, Netto MM. Tumor neuroendócrino primário de mama. Rev Fac Cienc Méd Sorocaba 2007;9:7-8.

3. Modlin IM, Shapiro MD, Kidd M. An analysis of rare carcinoid tumors: clarifying these clinical conundrums. World J Surg 2005;29:92-101.

4. Cedeño ALP, Pastor NV, Martinez MP, et al. Tumor neuroendocrino de la mama. Presentación de un caso. Ver Cubana obstet Ginecol 1999;25:194-6.

5. Righi L, Sapino A, Marchiò C, et al. Neuroendocrine differentiation in breast cancer: established facts and unresolved problems. Semin Diagn Pathol 2010;27:69-76.

6. Ogawa $\mathbf{H}$, Nishio A, Satake $H$, et al. Neuroendocrine tumor in the breast. Radiat Med 2008;26:28-32.

7. Kanthan R, Negreiros F, Kanthan SC. Colonic carcinoid metastatic to the breast. Arch Pathol Lab Med 2003;127:1373-5.

8. Rovera F, Masciocchi P, Coglitore A, et al. Neuroendocrine carcinomas of the breast. Int J Surg 2008;6(Suppl 1):S113-5.

This pdf has been created automatically from the final edited text and images.

Copyright 2012 BMJ Publishing Group. All rights reserved. For permission to reuse any of this content visit http://group.bmj.com/group/rights-licensing/permissions.

BMJ Case Report Fellows may re-use this article for personal use and teaching without any further permission.

Please cite this article as follows (you will need to access the article online to obtain the date of publication).

Graça SAR, Esteves J, Costa S, Vale S, Maciel J. Neuroendocrine breast cancer. BMJ Case Reports 2012;10.1136/bcr.12.2011.5343, Published XXX

Become a Fellow of BMJ Case Reports today and you can:

- Submit as many cases as you like

- Enjoy fast sympathetic peer review and rapid publication of accepted articles

Access all the published articles

- Re-use any of the published material for personal use and teaching without further permission

For information on Institutional Fellowships contact consortiasales@bmjgroup.com

Visit casereports.bmj.com for more articles like this and to become a Fellow

Keep up to date with all published cases by signing up for an alert (all we need is your email address) http://casereports.bmj.com/cgi/alerts/etoc 